\title{
Zinc Finger Protein GLIS2
}

National Cancer Institute

\section{Source}

National Cancer Institute. Zinc Finger Protein GLIS2. NCI Thesaurus. Code C105902.

Zinc finger protein GLIS2 (524 aa, $\sim 56 \mathrm{kDa}$ ) is encoded by the human GLIS2 gene. This protein is involved in the regulation of transcription and the repression of signaling pathways. 